\title{
GNLY wt Allele
}

National Cancer Institute

\section{Source}

National Cancer Institute. GNLY wt Allele. NCI Thesaurus. Code C120947.

Human GNLY wild-type allele is located in the vicinity of 2 p11.2 and is approximately 14 $\mathrm{kb}$ in length. This allele, which encodes granulysin protein, plays a role in defense responses to microbial infection. 